\title{
SALICYLIC ACID POSITIVELY AFFECTED PLANT GROWTH, PHOTOSYNTHETIC LEAF PIGMENTS AND FRUIT YIELD OF SUMMER SQUASH (Cucurbita pepo L.) GROWN UNDER DIFFERENT N-LEVELS
}

Elwan, M. W. M.* and R. S. A. El-Shatoury

Suez canal Univ., Fac. Agric., Dept. of Horticulture, Ismailia, Egypt

* Corresponding author.

E-mail addresses: Elwan_wasfy@yahoo.com (M.W.M. Elwan),

Tel/Fax numbers: 002-064-3201793

\begin{abstract}
Nitrogen $(\mathrm{N})$ fertilization plays a central role for improving yield in different vegetable crops and high $\mathrm{N}$ assimilation is desired to produce higher fruit yield. Several studies showed that salicylic acid (SA) application increases plant growth and productivity, but no attempts have been made to investigate the interaction effects of $\mathrm{SA}$ and $\mathrm{N}$-nutrition. The aim of this study was to analyze the effects of different $\mathrm{N}$ rates and SA concentrations, and their interaction on plant growth, photosynthetic pigments and fruit yield. Field experiments were carried out during two consecutive growing seasons under Egyptian conditions using different combinations of $\mathrm{N}$ and SA rates. Plant biomass and fruit yield were increased linearly in response to $\mathrm{N}$ addition from 0.0 to $90 \mathrm{~kg} / \mathrm{fed}$. in both years, however, this effect was true for photosynthetic pigments, especially chlorophyll a, b and total chlorophyll, in the second year of cultivation. Salicylic acid application showed mostly a significant increase in the previous traits under all N-rates. Carotenoids content in leaves was not affected significantly by $\mathrm{N}$ and $\mathrm{SA}$ in the first sampling date, however, in the second date it affected negatively by $\mathrm{N}$ fertilizer. The above mentioned results revealed a synergism between $\mathrm{N}$ fertilizer and SA application. This study showed that SA addition increased plant growth and yield mainly by increasing the $\mathrm{N}$ recovery from the soil.

Keywords: Squash, nitrogen, salicylic acid, plant biomass, chlorophyll and fruit production.
\end{abstract}

\section{INTRODUCTION}

$\mathrm{N}$ nutrition plays a significant role in both crop yield and quality (Sisson et al., 1991; Gastal and Lemaire, 2002; Wang et al., 2002; Stagnari et al., 2007; Petropoulos et al., 2008; Cabello et al., 2009; Zotarelli et al., 2009a; Konstantopoulou et al., 2010; He-xi et al., 2011). Since, N is required for the synthesis of nucleic acids and proteins, phospholipids and many secondary metabolites (Amtmann and Armengaud, 2009). Nitrate uptake and accumulation in plants primarily relates to the amount (Chen et al., 2004; Mantovani et al., 2005). However, a limited research effort has been carried to examine the effects of rates of the applied nitrogen on the yield of summer squash (Chance et al., 1999; Mohammad, 2004; El-Shatoury, 2005; Zotarelli et al., 2009b) which showed a significant effect. Farmers have increased application of $\mathrm{N}$ fertilizers to their land year by year (Wang et al., 2000), without considering the response of different species to $\mathrm{N}$ rate and forms. 
Adequate supply of $\mathrm{N}$ can promote plant growth and increase crop production (Collins and McCoy, 1997), but excessive and inappropriate use of chemical $\mathrm{N}$ fertilizers causes accumulation of compounds in the edible products. Such compounds may be harmful to humans and also cause environmental pollution and economical losses.

It is well documented that phenolic compounds exert their influence on physiological and biochemical processes including, photosynthesis, ion uptake, membrane permeability, enzyme activities, flowering, growth and development of plants and has diverse effects on tolerance to biotic and abiotic stress (Hayat et al., 2007\&2010; Arfan et al., 2007; Syeed et al., 2010; Wang et al., 2010\&2011; Nazar et al., 2011). One, such a natural compound is salicylic acid that may function as plant growth regulator (Arberg, 1981). It has been identified as an important signaling element involved in establishing the local and systemic disease resistance response of plants after pathogen attack (Alvarez, 2000). After a pathogen attack, SA levels often increases and induced the expression of pathogenesis-related proteins and initiates the development of systemic acquired resistance and hypersensitive response (Grüner et al., 2003; Kachroo et al., 2005; Radwan et al., 2006; Radhakrishnan and Balasubramanian, 2009).

The metabolic aspects of plants, supplied with SA or its derivatives, shifted to a varied degree, depending on the plant type and the mode of application of SA. Out of the various concentrations of SA used, Fariduddin et al. (2003) observed maximum increase in dry matter accumulation, chlorophyll and activity of nitrate reductase (NR) at a concentration of $10^{-5} \mathrm{M}$, supplemented to the leaves of the standing plants of Brassica juncea but the concentrations, above that proved inhibitory. Moreover, wheat seedlings, raised from the grains soaked in $10^{-5} \mathrm{M}$ of SA possessed more number of leaves, higher pigments content, higher fresh and dry mass and higher activity of NR, compared with water soaked, control (Hayat et al., 2005). Recently, Nazar et al. (2011) reported highest chlorophyll content in mungbean plants supplied with $0.5 \mathrm{mM} \mathrm{SA}$. In the former study, SA application at low concentration $\left(10^{-6} \mathrm{M}\right)$ positively increased the foliage fresh and dry weight, fruit number, average fruit weight, fruit yield, vitamin $\mathrm{C}$, carotenoids content, cuticle thickness of fruit pericarip and translocation of sugars from leaves to fruits. It was found that $S A$ treatment $\left(10^{-6} \mathrm{M}\right)$ caused a reduction in peroxidase and increasing of invertase activities of pepper leaves and fruits (Elwan and El-Hamahmy, 2009).

Nonetheless, soaking the seeds of Vigna mungo in SA solutions (10$150 \mu \mathrm{m})$ decreased the contents of chlorophyll and carotenoid (Anandhi and Ramanujam, 1997). Also, the results of Wang et al. (2011) indicated that treated Vallisneria natans (Lour.) Hara plants with SA at 10 and $100 \mu \mathrm{M}$ decreased total chlorophyll and carotenoids content.

Summer squash is one of the most popular and widely used vegetable crops in the world. Approximately 1.7 Million ha are planted yearly with squash, pumpkin and gourd all over the world and yielding 22.14 Million tons with an average of 13.3 tons/ha. Egypt produced 700 thousand tons from around 40 thousand ha from squash, pumpkin and gourd with an average of 17.5 tons/ha (FAOSTAT, 2009). 
Phenolic acids based regulation of nitrogen metabolism due to environmental constraints require more study to understand their effects on growth and yield production. It is clear that SA plays a positive role in biotic and a biotic stress; however, little information has been reported about the role of SA in N-nutrition. Therefore, effects of exogenous SA on morphological and photosynthetic traits of summer squash cv. Eskandrani is determined to understand physiological responses to $\mathrm{N}$-nutrition. The objectives of this study were to investigate role of SA in regulation of plant growth, leaf pigments and fruit yield of summer squash (Cucurbita pepo L. cv. Eskandrani) plants under different $\mathrm{N}$-rates.

\section{MATERIALS AND METHODS}

\section{Plant material and growth conditions}

Two field experiments were conducted in consecutive fall growing season of 2011 and 2012 at the Experimental Research Farm, Faculty of Agriculture, Suez Canal University, Ismailia, Egypt to investigate the effect of nitrogen levels and Salicylic acid application and their interaction on plant growth, leaf pigments and fruit yield of summer squash cv. Eskandarani.

Randomized soil samples were collected at $0.0-50.0 \mathrm{~cm}$ depth, before each plantation and homogenized together to determine the physicochemical characteristics of air-dried, crushed and sieved $(<2 \mathrm{~mm})$ soil in accordance to the methods of Gee and Bauder (1986) and Sparks et al. (1996). Soluble cations $\mathrm{Na}^{+}, \mathrm{K}^{+}, \mathrm{Ca}^{2+}$ and $\mathrm{Mg}^{2+}$ and anions $\mathrm{HCO}_{3}{ }^{-}$and $\mathrm{Cl}^{-}$ were determined in the soil solution (Richards, 1954). Sulfate $\left(\mathrm{SO}_{4}{ }^{2-}\right)$ was precipitated by barium chloride as barium sulfate and gravimetrically determined (Jackson, 1967). Electrical conductivity of the saturated soil paste extract expressed asdSm-1 was measured using a conductivity meter model Jenway 3310 (Jenway Ltd., Essex, Cambridge, UK) according to Richards (1954). Soil pH was determined by bench type Beckman glass electrode $\mathrm{pH}$ meter, in 1: 2.5 soil-water suspensions according to Page et al. (1982). The soil of the experimental site was sandy soil $(85.21 \%$ sand, $11.5 \%$ silt and $3.29 \%$ clay) with $\mathrm{pH} 8.27$, electrical conductivity (EC) $0.47 \mathrm{dSm}^{-1}$, calcium (Ca) $0.4 \mathrm{mM}$, magnesium $(\mathrm{Mg}) 0.3 \mathrm{mM}$, potassium (K) $0.3 \mathrm{mM}$, Na $3.0 \mathrm{mM}$, bicarbonate $\left(\mathrm{HCO}_{3}\right) 1.6 \mathrm{mM}$, chloride $(\mathrm{Cl}) 3.0 \mathrm{mM}$, and sulfate $\left(\mathrm{SO}_{4}\right) 0.05$ $\mathrm{mM}$. Before each planting, the experimental location was prepared. During preparation, a rate of $20 \mathrm{~m}^{3}$ of cattle manure plus $350 \mathrm{~kg}$ calcium super phosphate $\left(15.5 \% \mathrm{P}_{2} \mathrm{O}_{5}\right)$ per Fadden were supplemented, then the soil of the site was cleared, ploughed, harrowed and divided into plots.

The experiments were laid-out in a split plot in randomized complete block design with three replicates. Experiment was subjected to combinations of three nitrogen levels and three salicylic acid concentrations. Nitrogen was supplied as ammonium nitrate at rate of $0.0,45$ and $90 \mathrm{~kg} \mathrm{~N} / \mathrm{fed}$. Salicylic acid supplied at rate of $0.0,10^{-6}$ and $10^{-3} \mathrm{M}$ as foliar spray. SA was initially dissolved in a few drops of dimethyl sulfoxide and the final volume was reached using distilled water, $\mathrm{pH}$ was adjusted with $\mathrm{KOH}(1.0 \mathrm{~N})$ to a value of 7.0. The solutions of $S A$ with a surfactant triton $0.1 \%$ were sprayed four times 
with 2 weeks intervals on the whole foliage in the morning (8-9 a.m.). The volume of sprayed solution ranged from $30 \mathrm{ml}$ to $50 \mathrm{ml}$ per plant each time, depending on plant development stage. The same amount of dionized water plus triton $0.1 \%$ was sprayed to the control plants. The sprays in all cases were carried out with a manual pump.

Main plots $(0.0,45$ and $90 \mathrm{~kg} \mathrm{~N} / \mathrm{fed}$ ) were 27 rows $0.5 \mathrm{~m}$ apart, each row $25 \mathrm{~m}$ in length and $1.0 \mathrm{~m}$ in width containing fifty plants at a spacing of $0.5 \mathrm{~m}$ within the row. Sup-plots $\left(0.0,10^{-6}\right.$ and $\left.10^{-3} \mathrm{M} \mathrm{SA}\right)$ were nine rows with three replicates. Each two adjacent experiment units (sub plots) were separated, on each side, by $1 \mathrm{~m}$ to protect against border effects. The environmental conditions were as follows: a $14 \mathrm{~h}$ photoperiod, temperature fluctuated between $35-40 / 23-26{ }^{\circ} \mathrm{C}$ day/night and a relative humidity ranged from $50 \%$ to $55 \%$.

Seeds of summer squash cv. Eskandrani were direct seeded by hand at a soil depth of $0.015 \mathrm{~m}$ on the third top of slope ridges, from the first of April to the mid of June 2011 and 2012. Nitrogen fertilizer levels were added at four equal doses 2, 4, 6 and 8 weeks after sowing, also, salicylic acid applied foliarly four times during growing seasons, added in the same time of nitrogen fertilizer addition. The soil moisture content was kept at an appropriate field capacity for sandy soil $(50-75 \%)$ as described by Klocke and Fischbach (1984) and Miles and Broner (1998). Recommended practices for disease and insect control were followed.

\section{Data collection and analysis \\ Plant biomass}

Foliage fresh and dry weights of 10 plants for each replicate were determined using gravimetric method. Dry weight was determined after fixing plant material at $90^{\circ} \mathrm{C}$ and drying at $70^{\circ} \mathrm{C}$ up to constant weight.

\section{Leaf pigments}

Chlorophyll a, b and carotenoid content of leaves were determined after 4 and 8 weeks from planting using a Spectro 22 spectrophotometer (Labomed Inco, USA, according to Lichenthaler and Wellburn (1983), and then calculated as $\mathrm{mg} / \mathrm{g}$ fresh weight.

\section{Fruit yield}

Fresh weights of fruits at commercial fresh market maturity were recorded four times per week on all plants in the experimental unit starting after 4 weeks from sowing. Fruits were harvested when they reached marketable size (over $12 \mathrm{~cm}$ ).

\section{Statistical analysis}

The results were evaluated using descriptive statistics and analysis of variance (ANOVA). Using two-way ANOVA, the effect of nitrogen levels and salicylic acid application as well as their interaction were evaluated by Fisher's F-test, followed by Duncan's multiple range test for comparing the nine $\mathrm{N} \times \mathrm{SA}$ combinations. All tests were performed at a significance level a of 0.05 . Calculations were carried out using the software package Statistica ${ }^{\mathrm{TM}}$ for Windows version6.1 (Statsoft Inc., 2001, Tulsa, Oklahoma, USA). 


\section{RESULTS}

Nitrogen, SA and their interaction strongly affect the leaf chlorophyll $a, b$ and total chlorophyll content in both sampling dates and years have been observed, however leaf cartenoids content was affected only by $\mathrm{N}$-fertilization (Table 1). The results (Table 1) indicated that $\mathrm{N}$-fertilized summer squash plants had the significant highest chlorophyll a, b and total chlorophyll, however, non-fertilized plants with nitrogen had the highest leaf carotenoids content than fertilized plants, especially in the second sampling date (8 weeks). Data also (Table 1), proved that no significant differences were found between plants received $45 \mathrm{~kg} / \mathrm{ha}$ and $90 \mathrm{~kg} / \mathrm{fed}$ for chlorophyll a,b and total measured in the first sampling date (4 weeks) of both years. Nonetheless, in the second sampling date (8 weeks), chlorophyll a,b and total in the second year as well as chlorophyll a in the first year were significantly higher in plants fertilized with higher nitrogen level (90 kg/fed) comparing with medium nitrogen level $(45 \mathrm{~kg} / \mathrm{fed})$.

High values of chlorophyll $a, b$ and total appeared in foliar sprayed plants with SA at low $\left(10^{-6} \mathrm{M}\right)$ concentration than those treated with high SA $\left(10^{-3} \mathrm{M}\right)$ concentration or control treatments in both years and sampling dates, however, carotenoids content did not affected by SA application (Figure 1).

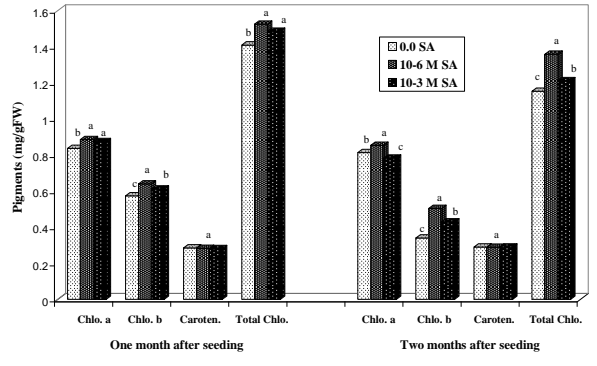

a

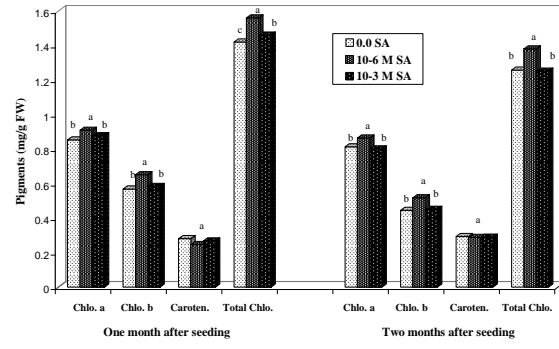

b

Figure 1: Effect of SA concentrations on leaf pigments of summer squash, (a) season of 2011 and (b) season of 2011.

In the first sampling date, higher chlorophyll a and total chlorophyll in both cultivation years were found in plants sprayed with low SA concentration and fertilized with nitrogen at medium and high levels (45 and $90 \mathrm{~kg} / \mathrm{fed}$ ), however, the highest chlorophyll b was observed in plants received nitrogen at medium level (45 kg/fed) and sprayed with SA at $10^{-6} \mathrm{M}$ (Table 1). While, in the second sampling date, higher chlorophyll a,b and total chlorophyll were associated with plants received high nitrogen level and low SA concentration (Table 1).

Nitrogen fertilizer, salicylic acid and their interaction significantly affected the marketable yield of squash in both seasons in addition to plant fresh weight in the first season, however, plant fresh and dry weights in the 
second season as well as dry weight\% in both seasons affected significantly by only nitrogen fertilizer, while plant dry weight in the first season affected by nitrogen fertilizer and salicylic acid (Table 2). The results indicated that the significant highest plant fresh and dry weights and fruit yield were attributed with the $90 \mathrm{~kg} \mathrm{~N} / \mathrm{fed}$ and $10^{-6} \mathrm{M} \mathrm{SA}$ (Table 2 \& Figure 2), however, plant dry weight percentage was decreased with increasing nitrogen level (Table 2). a

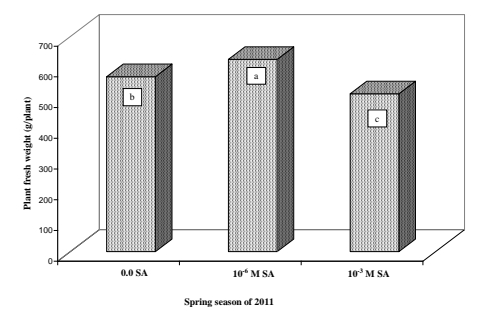

C

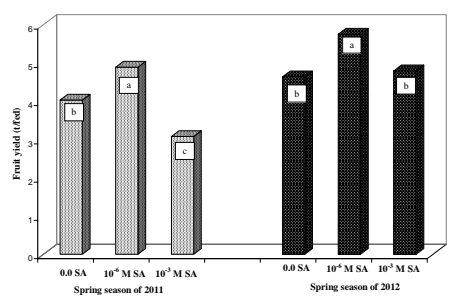

Figure 2: Effect of SA concentrations on plant fresh weight (a \&b) and fruit yield (c) of summer squash during summer seasons of 2011 and 2012.

Regarding the interaction between nitrogen levels and SA concentrations, the data (Table 2) revealed that the significant highest plant fresh and dry weight in addition to fruit yield were attributed with plants received high nitrogen level and low SA (Table 2), however, plant dry weight percentage was significantly higher in plants without nitrogen fertilizer and SA application (Table 2). In this respect, the yield was significantly increased in sprayed plants with low SA by $15.3 \%, 31.9 \%$ and $15.37 \%$ in the first season and by $49.49 \%, 6.3 \%$ and $34.45 \%$ in the second season, in plants received nitrogen fertilizer at $0.0,107.5$ and $215 \mathrm{~kg} / \mathrm{ha}$, respectively. The increasing in plant fresh and dry weights by application of low SA concentration under nitrogen levels followed the same way as fruit yield.

Regarding correlations between measured parameters, the results in Table (3) revealed that the morphological parameters such as plant fresh and dry weights and fruit yield positively correlated at significant level with chlorophyll $\mathrm{a}, \mathrm{b}$ and total chlorophyll, however, plant dry weight percentage negatively correlated at significant level with chlorophyll a, b and total chlorophyll. 
J. Plant Production, Mansoura Univ., Vol. 3 (7), July, 2012

1

2129 
Elwan, M. W. M. and R. S. A. El-Shatoury

2

2130 
Also, the results in Figure (3) revealed a significant positive correlation between total yield of summer squash and plant dry weight $\left(r=0.81746^{* * *}\right)$. On the contrary, a highly significant negative correlation has been found between plant dry weight percentage and total yield of summer squash $(r=-$ $\left.0.6515^{\star \star \star}\right)$.
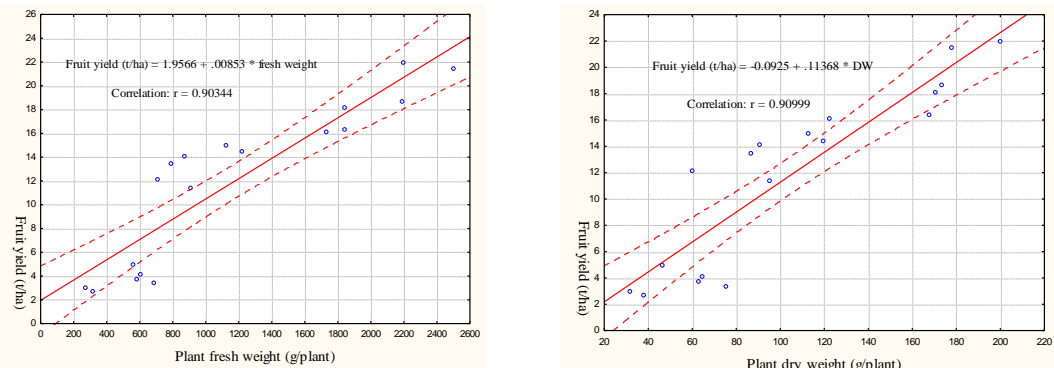

Figure (3): Regression of fruit yield on plant dry weight and plant dry weight percentage of summer squash plants grown for two summer seasons. The dashed lines represent the $95 \%$ confidence interval on the whole regression line.

Table (3): Correlation coefficient among chlorophyll pigments and morphological parameters

\begin{tabular}{|c|c|c|c|c|}
\hline & $\begin{array}{c}\text { Plant fresh } \\
\text { weight }\end{array}$ & Plant dry weight & $\begin{array}{l}\text { Plant dry } \\
\text { weight } \%\end{array}$ & Fruit yield \\
\hline & \multicolumn{4}{|c|}{ Summer season of 2010} \\
\hline Chlorophyll a & $0.77^{\star \star \star}$ & $0.81^{* \star *}$ & $-0.66^{\star *}$ & $0.76^{\star \star \star}$ \\
\hline Chlorophyll b & $0.83^{\star * *}$ & $0.88^{* \star *}$ & $-0.60^{\star *}$ & $0.82^{\star \star \star}$ \\
\hline Carotenoids & $-0.42 \mathrm{~ns}$ & $-0.41 \mathrm{~ns}$ & $0.49^{*}$ & $-0.40 \mathrm{~ns}$ \\
\hline \multirow[t]{2}{*}{ Total chlorophyll } & $0.83^{\star \star \star}$ & $0.87^{\star \star \star}$ & $-0.63^{\star *}$ & $0.81^{* \star *}$ \\
\hline & \multicolumn{4}{|c|}{ Summer season of 2011} \\
\hline Chlorophyll a & $0.71^{* *}$ & $0.73^{\star *}$ & $-0.61^{\star *}$ & $0.88^{\star \star \star}$ \\
\hline Chlorophyll b & $0.2^{* *}$ & $0.76^{\star \star *}$ & $-0.54^{*}$ & $0.91^{\star \star *}$ \\
\hline Carotenoids & $0.21 \mathrm{~ns}$ & $0.19 \mathrm{~ns}$ & $-0.15 \mathrm{~ns}$ & $0.39 \mathrm{~ns}$ \\
\hline Total chlorophyll & $0.73^{\star *}$ & $0.77^{\star \star \star}$ & $-0.57^{*}$ & $0.92^{\star \star \star}$ \\
\hline
\end{tabular}

\section{DISCUSSION}

The reported research was undertaken to improve our understanding of physiological processes determining the effect of SA for improving the nitrogen assimilation. $\mathrm{N}$-rate, salicylic acid and their interaction significantly influenced summer squash fruit yield and leaf photosynthetic pigments (chlorophyll a\&b and total chlorophyll) (Table 1\&2). Mostly, the highest leaf photosynthetic pigments were obtained when summer squash plants fertilized with high $\mathrm{N}$-rate and sprayed with low SA concentration $\left(10^{-6} \mathrm{M}\right)$. This effect was more pronounced in the second sampling date (after 8 weeks from seeding), this finding may be due to that summer squash plants at the second sampling date received all spraying doses of SA. 
It is well known that the nitrogen influences the structure and composition of photosynthetic apparatus. In crops, ribulose 1,5 , bisphosphate carboxylase (rubisco) content increases linearly with leaf $\mathrm{N}$ accumulation (Kumar et al., 2002). Also, it is a well-established fact that salicylic acid potentially generates a wide array of metabolic responses in plants and also affects the photosynthetic parameters such as chlorophyll $a$ and $b$ and plant water relations. SA might be involved in mobilization of internal tissue nitrate and chlorophyll biosynthesis to increase the functional state of the photosynthetic machinery in plants (Shi et al. 2006), as indicated in our results by increasing it plant fresh and dry weight of summer squash (Table 2). Exogenous application of SA was found to enhance the net photosynthetic rate, internal $\mathrm{CO}_{2}$ concentration, water use efficiency, stomatal conductance and transpiration rate in B. juncea (Fariduddin et al., 2003). The positive results regarding to increasing plant growth and fruit yield by SA could be due to the role of $S A$ in inducing plant defense mechanisms against zucchini yellow mosaic virus infection by inhibition or activation of some antioxidant enzymes, reduction of lipid peroxidation or induction of $\mathrm{H}_{2} \mathrm{O}_{2}$ accumulation in summer squash (Radwan et al., 2006). Also, Radhakrishnan and Balasubramanian (2009) reported that pretreatment of Curcuma longa plants with SA suppressed the pathogen-induced oxidative damage of soilborne Oomycete, Pythium aphanidermatum through higher accumulation of peroxidases and induced defense through the activities of protease inhibitors and strengthened the tolerance of turmeric rhizomes towards pathogen infection.

In the present study, as expected, a greater plant biomass was observed when $\mathrm{N}$ fertilizer rate increased. However, the results showed an evident $\mathrm{N} \times \mathrm{S}$ synergism since the addition of SA boosted plant biomass as $\mathrm{N}$ fertilizer rates increased (Table 2 and Figure 2), also, the photosynthetic pigments in this study increased significantly when summer squash plants sprayed with low SA at high N-rate (Table 1). Reported results regarding to SA application were in accordance with the results of Nazar et al. (2011) who found that treated mungbean plants with $0.5 \mathrm{mM} \mathrm{SA}$ improved significantly leaf chlorophyll content. However, our results were in contradiction with the previous reports on Vigna mungo by Anandhi and Ramanujam, (1997) and Wang et al. (2011) on Vallisneria natans (Lour.) Hara, who found that treated seeds and plants, respectively, with SA affected negatively the chlorophyll when SA ranged between 10-100 $\mu \mathrm{M}$. The decrease of total chlorophyll content was also detected in barley, radish and other plants exposed to SA (Canakci and Munzuroglu, 2009; Hayat et al., 2010).

The results of this experiment clearly showed a greater water uptake when $\mathrm{N}$ - rate was increased from 0.0 to $215 \mathrm{~kg} / \mathrm{ha}$, whereas the plant dry weight percentage was decreased with $\mathrm{N}$ fertilization increase and this effect did not affected by SA application (Table 2). It is clear, under N-deficiency the plants do not need to absorb more water, however, with increasing $\mathrm{N}$ rate the demand for water increased to create more plant growth and higher fruit yield. With regard to the effect SA on water uptake (plant dry weight percentage), the effects was not clear may be due to SA enhance stomatal 
conductance and transpiration rate as reported before in $B$. juncea by Fariduddin et al. (2003).

Nitrogen assimilation increased when SA was added at low concentration, where the indicated results showed that plant fresh and dry weights of summer squash improved by application of SA (Table 2 and Figure 2). High doses of SA were required to observe inhibitory action on plant growth of summer squash plants. The explanation for that thanks to higher levels of SA may inhibit nitrate uptake system and cause retardation in growth and development. Previous results reported by Wang and Li (2003) showed that the exogenous application of $50 \mu \mathrm{M}$ SA was beneficial for growth and development in comparison to high doses $(500 \mu \mathrm{M})$ of SA. Our results regarding to low $S A$ concentration may be explained by the fact of $S A$ influence transport of substances in plants (Krasavina, 2007). Also, previous studies reported that the nitrogen metabolism is an important aspect and exogenous application of SA was found to affect the activities of the enzymes of nitrate/nitrogen metabolism as well. Such a lower concentration of SA when sprayed enhanced NR activity when sprayed on the foliage of Brassica juncea plants (Fariduddin et al., 2003) and mungbean (Nazar et al., 2011). However, at higher concentrations, SA proved to be inhibitory. The treatment of maize plants with lower concentrations of SA also enhanced the uptake of nitrogen and activity of enzyme NR, whereas, higher concentrations were proved to be inhibitory (Jain and Srivastava, 1981).

Bio-productivity of plants has been one of the main topics of agricultural sciences and different experts (geneticists, plant breeders, biotechnologists, plant nutritionists, plant physiologists, etc) have been trying to describe it (Larque-Saavedra and Martin-Mex, 2007). The presented data proved that the yield of summer squash linearly increased by increasing $\mathrm{N}$ rate and this effect was efficiently at significant level when plants sprayed with SA at low concentration (Table 2). Also, significant positive correlations of plant fresh and dry weights and fruit yield with leaf photosynthetic pigments and a negative correlation of dry weight percentage with leaf photosynthetic pigments were detected in this study. In addition fruit yield correlated positively with plant fresh weight and negatively with percentage of plant dry weight. These data suggested that SA could play important role in the bioproductivity of plants and that could be linked to the observed effect of promoting the plant growth and fruit yield as mentioned earlier by Elwan and El-Hamahmy (2009) who found that low concentration of SA improved fruit yield by increasing invertase activity and translocation of sugar from leaves to fruits in pepper plants. The results of this study supported the hypothesis that SA favored growth and development by increasing nitrogen assimilation in summer squash plants. Here, according to our knowledge this is the first time that increasing $\mathrm{N}$ assimilation by application of $\mathrm{SA}$, however, there are other reports examined the increasing $\mathrm{N}$ use efficiency by application of sulfur in chinese spring onion (Liu et al., 2009), wheat (Salvagiotti et al., 2009) and broccoli (Elwan and Abd El-Hamed, 2011), which all of them found that sulfur application improved $\mathrm{N}$ assimilation.

Under $\mathrm{N}$-deficient $(0.0 \mathrm{~N}$-rates), the fruit yield slightly increased in plants treated with low SA (Table 2), this result supported the hypothesis that 
SA in summer squash play protective role for nutritional disorder. Previous research indicated that limited nitrogen availability reduces the growth and plant productivity and induces secondary metabolism (Lattenzio et al. 2009; Chisaki and Horiguchi 1997).

In summary, the increase in fruit yield in response to low $\mathrm{SA}\left(10^{-6} \mathrm{M}\right)$ concentration and high $\mathrm{N}$-rate $(90 \mathrm{~kg} / \mathrm{fed})$ was associated with a higher plant growth as a good indicator for more nutrient uptake by summer squash plant roots, in addition to increasing leaf photosynthetic pigments and water use efficiency. Therefore, this study shows that the concurrent management of $\mathrm{N}$ and $\mathrm{SA}$ is important for $\mathrm{N}$ recovery from the soil and sustaining high nitrogen assimilation for higher fruit production.

\section{REFERENCES}

Alverez, A.L., 2000. Salicylic acid in machinery of hypersensitive cell death and disease resistance. Plant Mol. Biol. 44, 429-442.

Amtmann, A., Armengaud, P., 2009. Effects of N, P, K and S on metabolism: new knowledge gained from multi-level analysis. Current Opinion in Plant Biology 12, 275-283.

Anandhi, S., Ramanujam, M.P., 1997. Effect of salicylic acid on black gram (Vigna mungo) cultivars. Ind. J. Plant Physiol. 2, 138-141.

Arberg, B., 1981. Plant growth regulators. Monosubstituted benzoic acid. Swed. Agric. Res., 11: 93-105.

Arfan, M., Arthar, R., Ashraf, M., 2007. Does exogenous application of salicylic acid through the rooting media modulate growth and photosynthetic capacity two differently adopted durum wheat cultivars under salt stress? J. Plant Physiol.164, 685-694.

Cabello, M.J., Castellanos, M.T., Romojaro, F., Martínez-Madrid, C., Ribas, F., 2009. Yield and quality of melon grown under different irrigation and nitrogen rates. Agricultural Water Management 9 6, $866-874$.

Canakci, S., Munzuroglu, O., 2009. Effects of salicylic acid on growth and chlorophyll destruction of some plant tissues. World J. Agric. Sci. 5, 577-581.

Chance, W.O., Somda, Z.C., Mills, H.A., 1999. Effect of nitrogen form during the flowering period on zucchini squash growth and nutrient element uptake. Journal of Plant Nutrition 22(3), 597-607.

Chen, B.M., Wang, Z.W., Li, S.X., Wang, G.X., Song, H.X., Wang, X.N., 2004. Effect of nitrate supply on plant growth, nitrate accumulation, metabolic nitrate concentration and nitrate reductase activity in three leafy vegetables. Plant Sci. 167 (3), 635-643.

Chisaki, N., Horiguchi, T., 1997. Responses 273 of secondary metabolism in plants to nutrient deficiency. In Plant nutrition for sustainable food production and environment. Ando T, Fujita K, Mae T, Matsumoto $\mathrm{H}$, Mori S, Sekija J (Eds.) Kluwer academic publishers, pp. 341-345.

Collins, M., McCoy, J.E., 1997. Chicory production, forage quality, and response to nitrogen fertilization. Agron. J. 89, 232-238. 
El-Shatoury, R.S.A. 2005. Effects of plant density and nitrogenous fertilizer on growth characters of summer squash. M.Sc. Thesis, Department of Horticulture, Faculty of Agriculture, Suez Canal University, Ismailia, Egypt.

Elwan, M.W.M., AbdEl-Hamed, K.E., 2011. Influence of nitrogen form, growing season and sulfur fertilization on yield and the content of nitrate and vitamin C of broccoli. Scientia Horticulturae 127, 181-187.

Elwan, M.W.M., El-Hamahmy, M.A.M., 2009. Improved productivity and quality associated with salicylic acid application in greenhouse pepper. Scientia Horticulturae 122, 521-526.

FAOSTAT, 2009. http://faostat.fao.org/site/567/default.aspx\#ancor.

Fariduddin, Q., Hayat, S., Ahmad, A., 2003. Salicylic acid influences net photosynthetic rate, carboxylation efficiency, nitrate reductase activity and seed yield in Brassica juncea. Photosynthetica 41, 281-284.

Gastal, F., Lemaire, G., 2002. N uptake and distribution in crops: an agronomical and ecophysiological perspective. J. Exp. Bot. 53, 789799.

Gee, G. W., and J. W. Bauder. 1986. Particle-size analysis. In Methods of soil analysis, ed. A. Klute, 383-409. Madison, Wisc.: ASA and SSSA.

Grüner, R., Strompen, G., Pfitzner, A.J.P., Pfitzner, U.M., 2003. Salicylic acid and the hypersensitive response initiate distinct signal transduction pathways in tobacco that converge on the as-1-like element of the PR1 a promoter. European J. Biochem., 270: 4876.

Hayat, Q., Hayat, S., Irfan, M., Ahmad, A., 2010. Effect of exogenous salicylic acid under changing environment: A review. Environmental and Experimental Botany 68, 14-25

Hayat, S., Ali, B., Ahmad, A., 2007. Salicylic acid: biosynthesis, metabolism and physiological role in plants. In: S. Hayat and A. Ahmad (eds.), Salicylic Acid - A Plant Hormone, 1-14.

Hayat, S., Fariduddin, Q., Ali, B., and Ahmad, A.,2005. Effect of salicylic acid on growth and enzyme activities of wheat seedlings. Acta Agron. Hung., 53: 433-437.

He-xi, Z., Dao-cai, C., Qun, W., Jun, F., Xiao-yu, F., 2011. Yield and quality response of cucumber to irrigation and nitrogen fertilization under subsurface drip irrigation in solar greenhouse. Agricultural Sciences in China 10(6), 921-930.

Jackson, M.L., 1967. Soil Chemical Analysis. Prentice Hall Inc., Englewood Cliffs, N.J., Library of Congress, USA.

Jain, A., and Srivastava, H. S., 1981. Effect of salicylic acid on nitrate reductase activity in maize seedlings. Physiol. Plant., 51: 339-342.

Kachroo, P., Venugopal, S.C., Nvarre, D.A., Lapchyk, L., Kachroo, A., 2005. Role of salicylic acid and fatty acid desaturation pathways in ssi2mediated signaling. Pant. Physiol., 139: 1717-35.

Klocke, N.L., Fischbach, P.E., 1984. Estimating Soil Moisture by Appearance and Feel. University of Nebraska-Lincoln Extension. G84-690. 
Konstantopoulou, E., Kapotis, G., Salachas, G., Petropoulos, S.A., Karapanos, I.C., Passam, H.C., 2010. Nutritional quality of greenhouse lettuce at harvest and after storage in relation to $\mathrm{N}$ application and cultivation season. Scientia Horticulturae 125, 93.e1-93.e5.

Krasavina, M.S., 2007. Effect of salicylic acid on solute transport in plants. In: S. Hayat and A. Ahmad (eds.), Salicylic Acid - A Plant Hormone, 25-68.

Kumar, P.A., M.A.J. Parry, R.A.C. Mitchell, A. Ahmad, Y.P. Abrol, 2002. Photosynthesis and nitrogen use efficiency. In: Foyer $\mathrm{CH}$, Noctor $\mathrm{G}$, editors. Photosynthetic nitrogen assimilation and associated carbon and respiratory metabolism: advances in photosynthesis and respiration. Dordrecht: Springer, p. 23-34.

Larque-Saavedra, A., Martin-Mex, R., 2007. Effects of salicylic acid on the bioproductivity of plants. In: S. Hayat and A. Ahmad (eds.), Salicylic Acid - A Plant Hormone, 15-23.

Lattanzio, V.; Cardinali, A.; Ruta, C.; Fortunato, I.M.; Lattanzio, V.M.T.; Linsalata, V.; Cicco, N., 2009. Relationship of secondary metabolism to growth in oregano (Origanum vulgare L.) shoot cultures under nutritional stress. Environmental and Experimental Botany 65, 54-62.

Lichtenthaler, H.K., Wellburn, W.R., 1983. Determination of total carotenoids and chlorophylls $a$ and $b$ of leaf extracts in different solvents. Biochem. Soc. Trans. 11, 591-592.

Liu, S., He, H., Feng, G., Chen, Q., 2009. Effect of nitrogen and sulfur interaction on growth and pungency of different pseudostem types of Chinese spring onion (Allium fistulosum L.). Scientia Horticulturae 121, $12-18$.

Mantovani, J.R., Ferreira, M.E., Da Cruz, M.C.P., 2005. Lettuce growth and nitrate accumulation in relation to nitrogen fertilization. Hortic. Brasileira 23 (3), 758-762.

Miles, D.L., Broner, I., 1998. IRRIGATION, Estimating Soil Moisture. Colorado State University Extension Crop Series. No. 4.700.

Mohammad, M.J., 2004. Squash yield, nutrient content and soil fertility parameters in response to methods of fertilizer application and rates of nitrogen fertigation. Nutrient Cycling in Agroecosystems 68, 99-108.

Nazar, R., Iqbal, N., Syeed, S., Khan, N.A., 2011. Salicylic acid alleviates decreases in photosynthesis under salt stress by enhancing nitrogen and sulfur assimilation and antioxidant metabolism differentially in two mungbean cultivars. Journal of Plant Physiology 168, 807-815.

Page, A.L., Miller, R.H., Keeney, D.R., 1982. Methods of Soil Analysis. Part 2: Chemical and Microbiological Properties. ASA, Madison, WI.

Petropoulos, S.A., Olympios, C.M., Passam, H.C., 2008. The effect of nitrogen fertilization on plant growth and the nitrate content of leaves and roots of parsley in the Mediterranean region. Scientia Horticulturae 118, 255-259.

Radhakrishnan, N., Balasubramanian, R., 2009. Salicylic acid induced defense responses in Curcuma longa (L.) against Pythium aphanidermatum infection. Crop Protection 28, 974-979. 
Radwan, D.M., Fayez, K.A., Mahmoud, S.Y., Hamad, A., Lu, G., 2006. Salicylic acid alleviates growth inhibition and oxidative stress caused by zucchini yellow mosaic virus infection in Cucurbita pepo leaves. Physiological and Molecular Plant Pathology 69, 172-181

Richards, L.A. (Ed.), 1954. Diagnosis and improvement of saline and alkali soils. US Salinity Lab., US Department of Agriculture Handbook 60. California, USA.

Salvagiotti, F., Castellar, J.M., Miralles, D.J., Pedrol, H.M., 2009. Sulfur fertilization improves nitrogen use efficiency in wheat by increasing nitrogen uptake. Field Crops Research 113, 170-177.

Shi, Q., Bao, Z., Zhu, Z., Ying, Q., Qian, Q., 2006. Effects of 321 different treatments of salicylic acid on heat tolerance, chlorophyll fluorescence and antioxidant enzyme activity in seedlings of Cucumis sativa L. Plant Growth Reg. 48(2), 127-135.

Sisson, V.A., Rufty, T.W., Williamson, R.E., 1991. Nitrogen-use efficiency among flue-cured tobacco genotypes. Crop Sci. 31, 1615-1620.

Sparks, D. L., A. L. Page, P. A. Helmke, R. H. Loeppert, P. N Soltanpour, M. A. Tabatabai, C.T. Johnston, and M. E. Sumner. 1996. Methods of soil analysis. Madison, Wisc.: ASA and SSSA.

Stagnari, F., Di Bitetto, V., Pisante, M., 2007. Effects of $\mathrm{N}$ fertilizers and rates on yield, safety and nutrients in processing spinach genotypes. Scientia Horticulturae 114, 225-233.

Statsoft, Inc. 2001. STATISTICA fuer Windous [Software-system fuer Datenanalyse] Version 6. www. Statsoft.com.

Syeed, S., N.A., Anjum, R. Nazar, N. Iqbal, A. Masood, N.A. Khan, 2010. Salicylic acid-mediated changes in photosynthesis, nutrients content and antioxidant metabolism in two mustard (Brassica juncea L.) cultivars differing in salt tolerance. Acta Physiol Plant., doi:10.1007/s11738-010-12614-7.

Wang, A.M., Zhang, F.K., Huang, L.F., Yin, X.P., Li, H.F., Wang, Q.Y., 2010. New progress in biocatalysis and biotransformation of flavonoids. $J$. Med. Plants Res. 4,847-56.

Wang, M., Li, Z., 2003. Nonideal gas flow and heat transfer in micro- and nanochannels using the direct simulation Monte Carlo method. Phys. Rev. E 68(4), 046704 - 046710.

Wang, Y., Dai, C.C., Zhao, Y. W., Peng, Y., 2011. Fungal endophyte-induced volatile oil accumulation in Atractylodes lancea plantlets is mediated by nitric oxide, salicylic acid and hydrogen peroxide. Process Biochemistry 46, 730-735.

Wang, Z.-H., Wang, L., He, C.Y., Wang, H., Kui, X.L., Jiang, Z.X., 2000. Studies on effect of over $\mathrm{N}$ fertilization on nitrate accumulation in different vegetables and its regulation. Agro-environ. Protect. 19 (1), $46-49$.

Wang, Z.-H., Zong, Z.-Q., Li, S.-X., Chen, B.-M., 2002. Nitrate accumulation in vegetables and its residual in vegetable fields. Environ. Sci. 23, 7983. 
Zotarelli, L., Dukes, M.D., Scholberg, G.M.S., Muñoz-Carpena, R., Icerman, J., 2009 a. Tomato nitrogen accumulation and fertilizer use efficiency on a sandy soil, as affected by nitrogen rate and irrigation scheduling. Agricultural Water Management 96, 1247-1258.

Zotarelli, L., Dukes, M.D., Scholberg, G.M.S., Hanselman, T., Femminella, L., Muñoz-Carpena, R., 2009 b. Nitrogen and water use efficiency of zucchini squash for a plastic mulch bed system on a sandy soil. Scientia Horticulturae 116, 8-16.

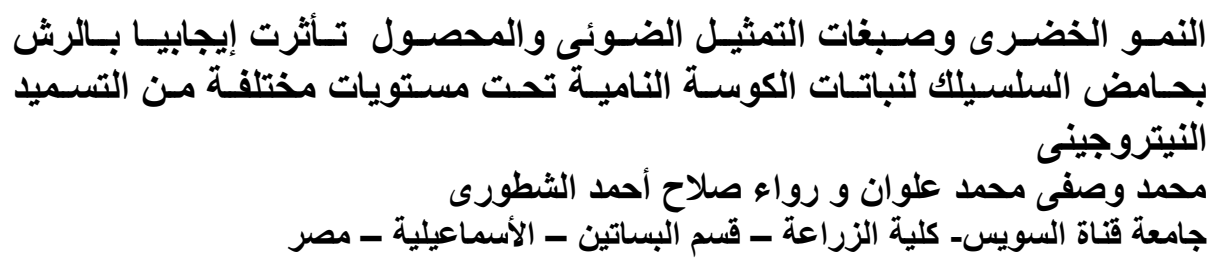

يلعب السماد النيتروجينى دورا مركزيا لتحسين المحصول في مختلف محاصيل الخضر و التمثيل

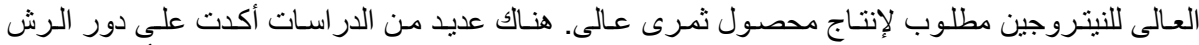

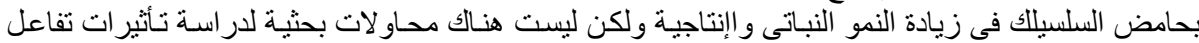

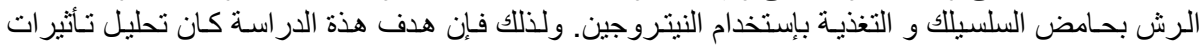

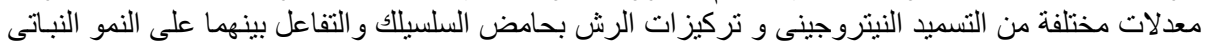

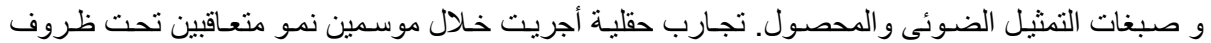

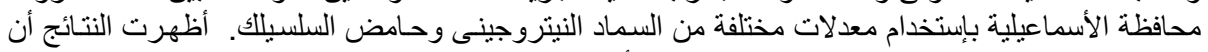

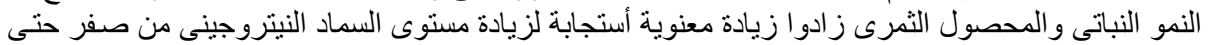

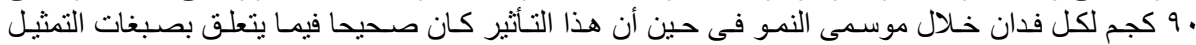

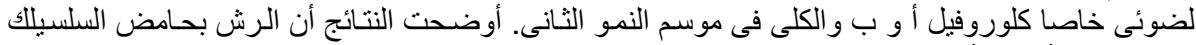

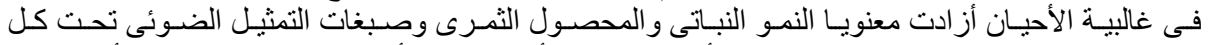

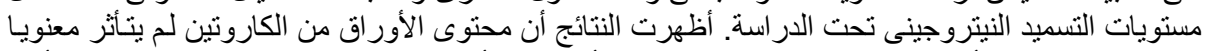

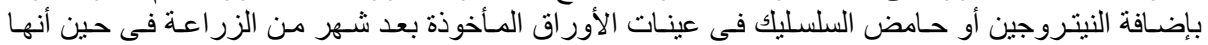

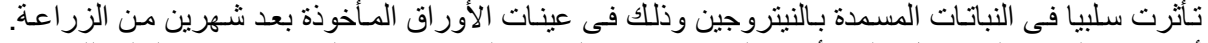

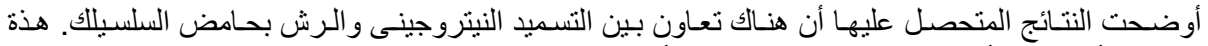

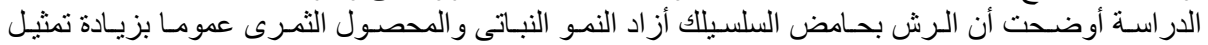

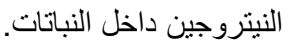

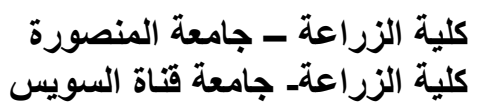

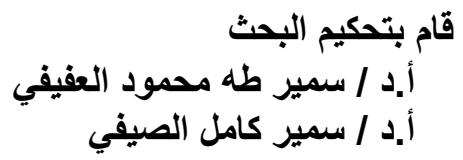

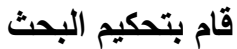
أ.د / أد / سمير كامل الصيفي مدود العي 
J. Plant Production, Mansoura Univ., Vol. 3 (7), July, 2012 
J. Plant Production, Mansoura Univ., Vol. 3 (7): 2123 - 2138, 2012

Table 1: Effect of nitrogen levels and salicylic acid concentrations on the leaf pigments $(\mathrm{mg} / \mathrm{g} \mathrm{FW})$ of summer squash.

\begin{tabular}{|c|c|c|c|c|c|c|c|c|c|}
\hline \multirow{3}{*}{$\begin{array}{l}N \text { levels } \\
\text { (Kg/fed.) }\end{array}$} & \multirow{3}{*}{$\begin{array}{l}\text { SA concentrations } \\
\text { (M) }\end{array}$} & \multicolumn{4}{|c|}{4 weeks from seeding } & \multicolumn{4}{|c|}{8 weeks from seeding } \\
\hline & & Chlo.a & Chlo.b & Total Chlo. & Caroten. & Chlo.a & Chlo.b & Caroten. & Total Chlo. \\
\hline & & \multicolumn{8}{|c|}{ Summer season of 2011} \\
\hline \multirow{3}{*}{0.0} & 0.0 & $0.6756 \mathrm{c}$ & $0.2639 \mathrm{f}$ & $0.9395 \mathrm{e}$ & $0.2892 \mathrm{a}$ & $0.7037 \mathrm{~d}$ & $0.2630 \mathrm{e}$ & $0.2915 \mathrm{a}$ & $0.9667 \mathrm{f}$ \\
\hline & $10^{-6}$ & $0.8104 \mathrm{~b}$ & $0.3792 \mathrm{e}$ & $1.1896 \mathrm{~d}$ & $0.2832 a b$ & $0.7894 \mathrm{c}$ & $0.3184 \mathrm{~d}$ & $0.2898 \mathrm{ab}$ & $1.1078 \mathrm{~d}$ \\
\hline & $10^{-3}$ & $0.7938 \mathrm{~b}$ & $0.3826 \mathrm{e}$ & $1.1763 \mathrm{~d}$ & $0.2821 \mathrm{ab}$ & $0.6223 \mathrm{e}$ & $0.4146 \mathrm{c}$ & $0.2908 \mathrm{a}$ & $1.0369 \mathrm{e}$ \\
\hline \multicolumn{2}{|r|}{ Mean } & $0.7599 \mathrm{~b}$ & $0.3419 \mathrm{~b}$ & $1.102 \mathrm{~b}$ & $0.2848 \mathrm{a}$ & $0.7051 \mathrm{c}$ & $0.332 \mathrm{c}$ & $0.2907 \mathrm{a}$ & $1.0370 \mathrm{~b}$ \\
\hline \multirow{3}{*}{107.5} & 0.0 & $0.9163 \mathrm{a}$ & $0.7508 \mathrm{~b}$ & $1.6670 \mathrm{ab}$ & $0.2821 \mathrm{ab}$ & $0.8266 \mathrm{c}$ & $0.5081 \mathrm{~b}$ & $0.2882 \mathrm{ab}$ & $1.3348 \mathrm{c}$ \\
\hline & $10^{-6}$ & $0.9239 \mathrm{a}$ & $0.7944 \mathrm{a}$ & $1.7182 \mathrm{a}$ & $0.2799 \mathrm{~b}$ & $0.8457 \mathrm{bc}$ & $0.5760 \mathrm{a}$ & $0.2876 \mathrm{ab}$ & $1.4217 \mathrm{~b}$ \\
\hline & $10^{-3}$ & $0.9059 \mathrm{a}$ & $0.6574 \mathrm{~d}$ & $1.5633 \mathrm{c}$ & $0.2818 \mathrm{ab}$ & $0.8298 \mathrm{c}$ & $0.4465 \mathrm{c}$ & $0.2883 \mathrm{ab}$ & $1.2762 \mathrm{c}$ \\
\hline \multicolumn{2}{|r|}{ Mean } & $0.9154 \mathrm{a}$ & $0.7342 \mathrm{a}$ & $1.6500 \mathrm{a}$ & $0.2813 \mathrm{a}$ & $0.8340 \mathrm{~b}$ & $0.5102 \mathrm{a}$ & $0.2880 \mathrm{~b}$ & $1.3440 \mathrm{a}$ \\
\hline \multirow{3}{*}{215} & 0.0 & $0.9169 \mathrm{a}$ & $0.7036 \mathrm{c}$ & $1.6205 \mathrm{bc}$ & $0.2810 \mathrm{~b}$ & $0.9089 \mathrm{a}$ & $0.2474 \mathrm{e}$ & $0.2889 \mathrm{ab}$ & $1.1563 \mathrm{~d}$ \\
\hline & $10^{-6}$ & $0.9224 \mathrm{a}$ & $0.7451 \mathrm{~b}$ & $1.6674 \mathrm{ab}$ & $0.2821 \mathrm{ab}$ & $0.9260 \mathrm{a}$ & $0.6169 \mathrm{a}$ & $0.2859 \mathrm{~b}$ & $1.5430 \mathrm{a}$ \\
\hline & $10^{-3}$ & $0.9219 \mathrm{a}$ & $0.7937 \mathrm{a}$ & $1.7155 \mathrm{a}$ & $0.2795 \mathrm{~b}$ & $0.8952 \mathrm{ab}$ & $0.4262 \mathrm{c}$ & $0.2891 \mathrm{ab}$ & $1.3214 \mathrm{c}$ \\
\hline \multicolumn{2}{|r|}{ Mean } & $0.9204 \mathrm{a}$ & $0.7474 \mathrm{a}$ & $1.6680 \mathrm{a}$ & $0.2809 \mathrm{a}$ & $0.9100 \mathrm{a}$ & $0.4302 \mathrm{~b}$ & $0.2880 \mathrm{~b}$ & $1.3400 \mathrm{a}$ \\
\hline & & \multicolumn{8}{|c|}{$P$ value } \\
\hline \multicolumn{2}{|c|}{ Nitrogen $(\mathrm{N})$} & $0.0000^{\star \star \star}$ & $0.0000^{\star \star \star}$ & $0.0000^{\star \star \star}$ & $0.1233 \mathrm{~ns}$ & $0.0000^{\star * \star}$ & $0.0000^{\star * *}$ & $0.0326^{*}$ & $0.0000^{\star * *}$ \\
\hline \multirow{2}{*}{\multicolumn{2}{|c|}{$\frac{\text { Salicylic acid (SA) }}{N^{\star} S A}$}} & $0.0026^{\star \star}$ & $0.0004^{\star * \star}$ & $0.0004^{\star \star \star}$ & $0.2993 \mathrm{~ns}$ & $0.0017^{\star \star}$ & $0.0000^{\star \star \star}$ & $0.1792 \mathrm{~ns}$ & $0.0000^{\star \star \star}$ \\
\hline & & $0.0017^{\star \star}$ & $0.0000^{* * *}$ & $0.0002^{\star \star \star}$ & $0.4747 \mathrm{~ns}$ & $0.0102^{*}$ & $0.0000^{\star \star \star}$ & $0.7941 \mathrm{~ns}$ & $0.0002^{\star * \star}$ \\
\hline & & \multicolumn{8}{|c|}{ Summer season of 2012} \\
\hline \multirow{3}{*}{0.0} & 0.0 & $0.7256 \mathrm{~d}$ & $0.2739 \mathrm{~g}$ & $0.9995 \mathrm{~g}$ & $0.2842 \mathrm{a}$ & $0.6937 \mathrm{f}$ & $0.2630 \mathrm{f}$ & $0.2965 \mathrm{a}$ & $0.9567 \mathrm{~g}$ \\
\hline & $10^{-6}$ & $0.8604 \mathrm{~b}$ & $0.3892 \mathrm{e}$ & $1.2496 \mathrm{e}$ & $0.2632 a b$ & $0.7994 \mathrm{e}$ & $0.3380 \mathrm{e}$ & $0.2948 a$ & $1.1378 \mathrm{e}$ \\
\hline & $10^{-3}$ & $0.7888 \mathrm{c}$ & $0.3526 \mathrm{f}$ & $1.1423 \mathrm{f}$ & $0.2396 \mathrm{~b}$ & $0.6923 \mathrm{f}$ & $0.3446 \mathrm{e}$ & $0.2958 \mathrm{a}$ & $1.0369 \mathrm{f}$ \\
\hline \multicolumn{2}{|r|}{ Mean } & $0.7916 \mathrm{~b}$ & $0.3386 \mathrm{~b}$ & $1.1301 \mathrm{~b}$ & $0.2623 \mathrm{a}$ & $0.7285 \mathrm{c}$ & $0.3153 \mathrm{c}$ & $0.2957 \mathrm{a}$ & $1.0438 \mathrm{c}$ \\
\hline \multirow{3}{*}{107.5} & 0.0 & $0.9063 \mathrm{ab}$ & $0.7358 \mathrm{~b}$ & $1.6420 \mathrm{bc}$ & $0.2821 \mathrm{a}$ & $0.8366 \mathrm{~d}$ & $0.5231 \mathrm{c}$ & $0.2882 \mathrm{abc}$ & $1.3598 \mathrm{c}$ \\
\hline & $10^{-6}$ & $0.9339 \mathrm{a}$ & $0.8044 \mathrm{a}$ & $1.7382 \mathrm{a}$ & $0.2799 \mathrm{a}$ & $0.8657 \mathrm{c}$ & $0.5860 \mathrm{~b}$ & $0.2876 \mathrm{abc}$ & $1.4517 \mathrm{~b}$ \\
\hline & $10^{-3}$ & $0.9109 \mathrm{a}$ & $0.644 \mathrm{~d}$ & $1.5583 \mathrm{~d}$ & $0.2818 \mathrm{a}$ & $0.8148 \mathrm{de}$ & $0.4565 \mathrm{~d}$ & $0.2883 a b c$ & $1.2712 \mathrm{~d}$ \\
\hline \multicolumn{2}{|r|}{ Mean } & $0.9170 \mathrm{a}$ & $0.7292 \mathrm{a}$ & $1.6462 \mathrm{a}$ & $0.2813 a$ & $0.8390 \mathrm{~b}$ & $0.52185 \mathrm{~b}$ & $0.2880 \mathrm{~b}$ & $1.3609 \mathrm{~b}$ \\
\hline \multirow{3}{*}{215} & 0.0 & $0.9270 \mathrm{a}$ & $0.6936 \mathrm{c}$ & $1.6205 \mathrm{c}$ & $0.2760 \mathrm{a}$ & $0.9089 \mathrm{ab}$ & $0.5474 \mathrm{c}$ & $0.2939 \mathrm{ab}$ & $1.4563 \mathrm{~b}$ \\
\hline & $10^{-6}$ & $0.9324 \mathrm{a}$ & $0.7601 \mathrm{~b}$ & $1.6924 \mathrm{ab}$ & $0.2806 \mathrm{a}$ & $0.9260 \mathrm{a}$ & $0.6269 \mathrm{a}$ & $0.2809 \mathrm{bc}$ & $1.5530 \mathrm{a}$ \\
\hline & $10^{-3}$ & $0.9319 a$ & $0.7487 \mathrm{~b}$ & $1.6805 \mathrm{ab}$ & $0.2800 \mathrm{a}$ & $0.8952 \mathrm{~b}$ & $0.5512 \mathrm{c}$ & $0.2806 \mathrm{c}$ & $1.4464 \mathrm{~b}$ \\
\hline \multicolumn{2}{|r|}{ Mean } & $0.9304 \mathrm{a}$ & $0.7341 \mathrm{a}$ & $1.6645 \mathrm{a}$ & $0.2789 \mathrm{a}$ & $0.9100 \mathrm{a}$ & $0.5752 \mathrm{a}$ & $0.2852 \mathrm{~b}$ & $1.4852 \mathrm{a}$ \\
\hline & & \multicolumn{8}{|c|}{$P$ value } \\
\hline \multicolumn{2}{|c|}{ Nitrogen (N) } & $0.0000^{\star \star \star}$ & $0.0000^{\star \star \star}$ & $0.0000^{\star \star \star}$ & $0.1448 \mathrm{~ns}$ & $0.0000^{\star \star *}$ & $0.0000^{\star \star \star}$ & $0.02005^{*}$ & $0.0000^{\star \star \star}$ \\
\hline \multirow{2}{*}{\multicolumn{2}{|c|}{$\frac{\text { Salicylic acid (SA) }}{N^{\star} S A}$}} & $0.0046^{\star \star}$ & $0.0000^{\star \star \star}$ & $0.0000^{\star \star \star}$ & $0.3877 \mathrm{~ns}$ & $0.0000^{\star \star \star}$ & $0.0001^{\star \star \star}$ & $0.2399 \mathrm{~ns}$ & $0.0000^{\star \star \star}$ \\
\hline & & $0.0177^{*}$ & $0.0001^{* * *}$ & $0.0004^{\star * *}$ & $0.3158 \mathrm{~ns}$ & $0.0041^{* *}$ & $0.0002^{* \star *}$ & $0.3707 \mathrm{~ns}$ & $0.0001^{* \star *}$ \\
\hline
\end{tabular}

Values are the means of at least 3 samples per replicate. Values followed by the same letter within a column are not significantly different the $0.05 \%$ level of probability according to Duncan's multiple range test. ${ }^{* * *},{ }^{* \star}$ and ${ }^{*}$ significant at $0.1 \%, 1 \%$ and $5 \%$; NS: not significant. 
J. Plant Production, Mansoura Univ., Vol. 3 (7), July, 2012

Table 2: Effect of nitrogen levels and salicylic acid concentrations on the plant fresh and dry weights, plant dry weight percentage and cumulative fruit yield per fed of summer squash.

\begin{tabular}{|c|c|c|c|c|c|c|c|c|c|}
\hline \multirow[b]{2}{*}{$\begin{array}{l}\text { N levels } \\
\text { (Kg/fed.) }\end{array}$} & \multirow{2}{*}{$\begin{array}{l}\text { SA concentrations } \\
\text { (M) }\end{array}$} & \multicolumn{4}{|c|}{ Summer season of 2011} & \multicolumn{4}{|c|}{ Summer season of 2012} \\
\hline & & $\begin{array}{l}\text { Plant FW } \\
\text { (g) }\end{array}$ & $\begin{array}{c}\text { Plant DW } \\
(\mathrm{g})\end{array}$ & Plant DW\% & $\begin{array}{c}\text { Fruit yield } \\
\text { (t/fed) }\end{array}$ & $\begin{array}{l}\text { Plant FW } \\
(\mathrm{g})\end{array}$ & $\begin{array}{l}\text { Plant DW } \\
\text { (g) }\end{array}$ & Plant DW\% & $\begin{array}{c}\text { Fruit yield } \\
\text { (t/fed) }\end{array}$ \\
\hline \multirow{3}{*}{0.0} & 0.0 & $216.00 \mathrm{f}$ & $24.84 \mathrm{e}$ & $11.50 \mathrm{a}$ & $1.44 \mathrm{e}$ & $297.50 \mathrm{e}$ & $35.00 \mathrm{f}$ & $11.75 \mathrm{a}$ & $1.24 \mathrm{~h}$ \\
\hline & $10^{-6}$ & $208.00 \mathrm{f}$ & $19.88 \mathrm{e}$ & $9.60 \mathrm{abc}$ & $1.66 \mathrm{e}$ & $583.00 \mathrm{de}$ & 55.75 ef & $9.52 \mathrm{abc}$ & $1.86 \mathrm{~g}$ \\
\hline & $10^{-3}$ & $202.50 \mathrm{f}$ & $21.56 \mathrm{e}$ & $10.65 \mathrm{a}$ & $1.37 \mathrm{e}$ & $637.00 \mathrm{~d}$ & 69.40 ef & $10.89 a b$ & $1.55 \mathrm{gh}$ \\
\hline \multicolumn{2}{|r|}{ Mean } & $208.83 \mathrm{c}$ & $22.09 \mathrm{c}$ & $10.58 \mathrm{a}$ & $1.49 \mathrm{c}$ & $505.83 \mathrm{c}$ & $53.39 \mathrm{c}$ & $10.72 \mathrm{a}$ & $1.55 \mathrm{c}$ \\
\hline \multirow{3}{*}{45} & 0.0 & $575.00 \mathrm{de}$ & $58.91 \mathrm{~cd}$ & $10.25 \mathrm{ab}$ & $4.23 \mathrm{~d}$ & $835.00 \mathrm{~d}$ & $88.82 \mathrm{de}$ & $10.65 \mathrm{abc}$ & $5.86 \mathrm{e}$ \\
\hline & $10^{-6}$ & $620.00 \mathrm{~d}$ & $61.39 \mathrm{~cd}$ & $9.90 a b c$ & $5.58 \mathrm{c}$ & $1173.50 \mathrm{c}$ & $116.38 \mathrm{~cd}$ & $9.92 a b c$ & $6.23 \mathrm{~d}$ \\
\hline & $10^{-3}$ & $530.00 \mathrm{e}$ & $51.70 \mathrm{~d}$ & $9.75 \mathrm{abc}$ & $3.83 \mathrm{e}$ & $813.50 \mathrm{~d}$ & $78.00 \mathrm{de}$ & $9.47 \mathrm{abc}$ & $5.04 \mathrm{f}$ \\
\hline \multicolumn{2}{|r|}{ Mean } & $575.00 \mathrm{~b}$ & $57.33 \mathrm{~b}$ & $9.97 a$ & $4.55 \mathrm{~b}$ & $940.67 \mathrm{~b}$ & $94.40 \mathrm{~b}$ & $10.01 \mathrm{a}$ & $5.71 \mathrm{~b}$ \\
\hline \multirow{3}{*}{90} & 0.0 & $918.00 \mathrm{~b}$ & $75.68 \mathrm{~b}$ & $8.25 \mathrm{c}$ & $6.44 \mathrm{~b}$ & $1787.00 \mathrm{~b}$ & $145.24 \mathrm{bc}$ & $8.10 \mathrm{c}$ & $6.82 \mathrm{c}$ \\
\hline & $10^{-6}$ & $1050.00 \mathrm{a}$ & $86.25 \mathrm{a}$ & $8.25 \mathrm{c}$ & $7.43 \mathrm{a}$ & $2350.50 \mathrm{a}$ & $189.17 \mathrm{a}$ & $8.11 \mathrm{c}$ & $9.17 \mathrm{a}$ \\
\hline & $10^{-3}$ & $810.00 \mathrm{c}$ & $68.90 \mathrm{bc}$ & $8.50 \mathrm{bc}$ & $4.05 \mathrm{de}$ & $2021.00 \mathrm{~b}$ & $172.00 \mathrm{ab}$ & $8.57 \mathrm{bc}$ & $7.79 \mathrm{~b}$ \\
\hline \multicolumn{2}{|r|}{ Mean } & $926.00 \mathrm{a}$ & 76.94 a & $8.33 \mathrm{~b}$ & $5.97 \mathrm{a}$ & 2052.8 a & $168.80 \mathrm{a}$ & $8.26 \mathrm{~b}$ & $7.93 \mathrm{a}$ \\
\hline & & \multicolumn{8}{|c|}{ P value } \\
\hline \multicolumn{2}{|c|}{ Nitrogen (N) } & $0.0000^{\star \star \star}$ & $0.0000^{\star * \star}$ & $0.00205^{\star \star}$ & $0.0000^{\star * \star}$ & $0.0000^{\star \star \star}$ & $0.0000^{\star \star \star}$ & $0.0085^{\star \star}$ & $0.0000^{\star \star \star}$ \\
\hline \multirow{2}{*}{\multicolumn{2}{|c|}{$\frac{\text { Salicylic acid (SA) }}{\mathbf{N}^{*} \mathbf{S A}}$}} & $0.0001^{* * *}$ & $0.0247^{\star}$ & $0.29902 \mathrm{~ns}$ & $0.0000^{\star \star *}$ & $0.00156^{* *}$ & $0.0227^{\star}$ & $0.3249 \mathrm{~ns}$ & $0.0000^{* * *}$ \\
\hline & & $0.0019^{\star *}$ & $0.1009 \mathrm{~ns}$ & $0.48529 \mathrm{~ns}$ & $0.0000^{\star \star *}$ & $0.14552 \mathrm{~ns}$ & $0.18392 \mathrm{~ns}$ & $0.5244 \mathrm{~ns}$ & $0.0000^{* * *}$ \\
\hline
\end{tabular}




\section{Elwan, M. W. M. and R. S. A. El-Shatoury}

